\title{
The Future of Corporate Social Responsibility
}

\author{
Evyn Kron \\ Management Honors Thesis
}

MGMT 4513 


\section{Summary}

Corporate social responsibility (CSR) is a growing trend in the business world. The definition of CSR that I will be using comes from The Journal of Management in a review done by Herman Aguinis and Ante Glavas. The definition was given by Aguinis (2011: 855) and adopted by others (Rupp, 2011; Rupp, Williams, \& Aguilera, 2010) as: “context-specific organizational actions and policies that take into account stakeholders' expectations and the triple bottom line of economic, social, and environmental performance". I will also be reviewing another article from The Journal of Management and pinning down the main ideas behind the two articles and generating questions over the future of their findings in regards to CSR. I will also be calling on three other more recent articles dated between 2015 and 2016. The articles will be used to reference what has happened since the previous two articles to aid in answering and generating more questions. The articles come from The Journal of Management Policies and Practices, The Journal of Finance, and The McNair Scholars Research Journal.

As time moves forward, so does technology. With an increase in technology, the world becomes smaller with an increase in global connectivity through social media and more broadly the Internet. The global connectivity can be seen as "free advertising" as the media places a lot of attention on the responsible and irresponsible actions of corporations (McWilliams, Siegel 2011b). I will explore how I think the articles' findings will be impacted in the future as what corporations do is being broadcasted to a bigger and more demanding audience. One example company used is Tylenol as described by McWilliams and Siegel (2011b) by analyzing the massive recall in 1982 and the brand benefiting from taking such swift action. Another outcome of CSR is in the recruitment, retention, and productivity of employees when companies are seen more favorably because of CSR initiatives (Willard 2002). Three focuses of the questions generated will be over the effects of globalization, the effects on the companies' brand, and the 
effects on the companies' employees when they engage in CSR activities with an overarching focus on the effects on the companies' financials.

\section{Globalization}

With the constant growth of the Internet's users and their capabilities, the actions of firms are being seen by more people. Globalization can be explained as the increased interaction and connectedness of the world as people, goods, and concepts are spread with the Internet as their catalyst. Papoli (2015) notes that: "'[i]n the particular age of the Internet and global communication, a global firm is judged on the basis of whatever it does anywhere in the world, and, in our opinion, this means that 'what starts out local becomes quickly global'". Globalization means that firms must address the judgements of their stakeholders from a global level. The increased connectivity of the world can be good for firms who choose to act in ways that would be seen favorably by consumers and bad for firms who act negligently. Corporate actions being placed on a world-wide stage is also proving to make corporations more transparent, and in turn, engage in more CSR initiatives. Globalization brings up the first research question of: Will more firms participate in CSR as their audience grows? This means that the increased connectivity of the world causing more firms to participate in CSR will be explored.

Corporations must analyze their strategies from a global viewpoint because of how connected the world is. Papoli (2015) demonstrates this idea when he states that: "a concrete example of this vision of stakeholders on a global, rather than, local level is provided by the Sony Group, which has eliminated some chemical substances from its products all over the world even though those specific substances are banned only in Europe (Sony CSR Report 2006)". Papoli (2015) also goes on to share that the action taken by Sony demonstrates that they were fully aware that 
they were being judged by the entire world and rejecting a more "selective" means of conducting CSR. Sony could have only discontinued the use of the chemicals in Europe. By discontinuing the use in all countries that Sony operates in, the firm avoided receiving criticism from their European customers as well as from their customers in other countries. This example shows that firms must consider their possible judgements of their customers in every country they operate in.

McWilliams and Sigel (2011b) describe global connectivity as "free advertising" as the media places a lot of attention on the responsible and irresponsible actions of corporations. Consumers are alerted each time a company acts responsibly or each time a company acts irresponsibly because of the widespread use of the Internet and the media. A famous example of a company acting rightfully and proactively is Johnson \& Johnson with the Tylenol recall of 1982. Only some packages found in Chicago, Illinois of Tylenol were affected by the planted poison, but Johnson \& Johnson withdrew all packages of Tylenol on shelves nationwide. This course of action allowed Johnson \& Johnson to be seen as caring about their consumers and placing the consumer first as it withdrew 31 million bottles and offered free replacements (Rehak, 2002). This action was expensive, but saved Tylenol from harsh reactions and opinions from consumers. As noted by Zyglidopoulos and colleagues (2009): “[global connectivity] boosts the reputation of firms engaging in it and severely punishes firms that falter (such as BP in 2010)". The British Petroleum (BP) oil spill in the Gulf of Mexico was broadcasted on news channel after news channel where viewers could watch the oil spewing out into the ocean. The vividness of the action that was made possible by the media allowed consumers to form harsher impressions of the spill caused by BP. McWilliams and Siegel (2011) noted the effects of global connectivity on social media sites and noting how quickly content can go viral online by 
extending the reach of activist and journalists. This point also brings about the concept that the Internet not only increases awareness of corporate behavior, but also decreases the cost in reaching consumers. Social media posts can be seen by anyone across the world with access to the particular platform, and usually for free. This relatively new trend has amplified the effects of what is broadcasted or written in the news. If corporations were to implement CSR actions, global connectivity makes it much easier for the consumer to see what they have done. Globalization through the Internet also makes it much less expensive for corporations to advertise to consumers what positive actions they are taking.

With the increase in globalization came an increase in stakeholders' access to corporations' actions, but this connectivity also positively influences the need felt by corporations to act in socially responsible ways. Johnson and Greening (1999) were able to find that when corporate governance structures changed to include outside directors, firms' interests beyond shareholder expectations rose. This insight was noted by Aguinis and Glavas (2012) and added to with the discernment that: "firms are more likely to engage in CSR when their structures are more open to relationships with society". In this age of the Internet, it is virtually impossible for firms to not have some form of a relationship with society, intentionally or consequentially. Because society has so much access to the actions of firms through the media, firms are more likely to participate in socially responsible activities. Globalization has likewise increased the transparency, or openness, in firms.

The benefits felt by firms engaging in socially responsible actions correspondingly increases with the rise in global connectivity. The article by Aguinis and Glavas (2012) was in general dedicated to discovering the causal relationships involved in CSR. One of the findings was that "[the] CSR-outcomes relationship is strengthened when level of exposure and visibility are high 
and size of the company is large" (Aguinis and Glavas (2012). This finding means that companies have better results with CSR initiatives when they are more exposed and visible to stakeholders. With the level of connectivity of the world today, this relationship between visibility and CSR-outcomes is made stronger because companies are so visible. The relationship between firm visibility and CSR outcomes is not a new pattern. Fry, Keim, and Meiners developed this idea in 1982, noting that: "as firms have a higher degree of public contact, the relationship between CSR engagement and outcomes is stronger".

Fisher (2016) shares that other authors, too, have found that stakeholders are finding that firms have societal duties to uphold when stating that by 2009 , most stakeholders perceived that firms have "ethical and philanthropic obligations toward society" (Carroll \& Shabanna, 2010). As parts of the world become more connected, the demand for firms to be socially responsible grows. If firms choose to partake in socially beneficial activities, the actions are not always picked up by the media and advertised for free. It is becoming increasingly more popular for firms to broadcast their actions themselves or to signal stakeholders. As noted by Fisher (2016): "by 2015, 92\% of the largest 250 companies worldwide had some method of reporting CSR information, which is a 5\% increase over the levels of CSR reporting in 2008 (KPMG, 2015)". Additionally, according to KPMG 2015 International Survey of Corporate Responsibility, in 2011, just 68\% of the 100 largest firms included CSR information in their annual reports, but in 2015 the rate grew to $75 \%$ (Fisher, 2016). Due to the inevitable information symmetry between firms and stakeholders regarding companies' CSR activities, firms may provide signals to stakeholders to demonstrate their commitment to CSR (Clarkson et el, 2011). Globalization aids in allowing firms to showcase their CSR actions to the world, but only if they report it, leading to more and more firms signaling their stakeholders. 


\section{Branding}

A firm's brand is one of the most valuable assets it has. Firms work diligently to craft the perfect brand image for their products, because the brand is often the first interaction or judgement a consumer has with the product. Brand perception is a hefty reason why consumers choose one hotel over another or a branded cereal over a generic one. A continuing theme in the articles is how CSR positively impacts a firm's brand and therefore its competitiveness and likeability in the market. Papoli (2015) sums this up by stating that: "[o]ne of the most important intangible assets for firm's competitiveness is brand image, reflecting all that which leads to the firm". CSR initiatives can be used to enhance a brand's image and likeability. Papoli (2015) reinforces and expands upon the above statement by sharing that: "the brand must be able to meet stakeholders' expectations not only regarding visible components of the marketing mix (product/service, price, place, promotion), but also the "value system", including both economical and social values, with which they identify" (Hildebrand, Sen and Bhattacharya, 2011; Peloza and Shang, 2011; Russell and Russel, 2010). The importance of brand image leads to the second research question of: Can CSR be used to gain trust from consumers?

The growing need for firms to use and promote CSR actions in order to gain business and loyalty from consumers is noted by Auger et al. (2008) as they note an "ethical consumerism" phenomenon exists that attributes to the growing importance of the social components of the product and business process. In particular, there is an increasing need for companies to legitimize themselves, from a social as well as economical point of view, as contributing cells of the environmental system to which they belong and, through their actions, help to define (Papoli, 2015). Corporations are now being seen as part of society by consumers. With this idea comes a need for firms to step up and make socially beneficial contributions, which will in turn benefit 
their brand image. Another growing consumer trend is noted by Papoli (2015) as: "the increasing idea of 'dematerialization' which is the disassociation of brand from product. That is accomplished through the consumers' process of abstraction (Fournier, 1998)". Papoli (2015) shares that: "[t]he aim of this disassociation is to create new associations to the brand of a cognitive and emotive nature: affective associations of psychological and social wellbeing, of consumer self-identification, which accompany the material components of the product. The brand, therefore must be able to meet consumer expectations that have to do not only with the visible components of the marketing mix (product/service, price, place, promotion), but also with the value system including both economical and social values, with which the consumer identifies". The trend of dematerialization means that consumers identify with a brand on a new found level, which is that the brand from which they buy from is socially responsible. This concept gives firms another demand from consumers in order to gain a purchase. If this trend continues, firms that do not engage in CSR will no longer be relevant in the marketplace. McWilliams and Siegel (2011) reinforce this concept with the example of Tylenol; again, sharing that: "CSR may also increase the value of brands. Since the massive recall of Tylenol in 1982, the brand has inexorably linked with both quality and social responsibility". The actions taken by Tylenol allowed the brand to live on by regaining consumer trust.

Consumers desiring for firms to be good corporate citizens may lead to firms that implement CSR being able to benefit from their good reputation. McWilliams and Siegel (2011) summarize this concept when they assert that: "Fombrun and Shanley (1990) pointed out that good reputation may result in the ability to charge higher prices (Klein \& Leffler, 1981), enhance access to capital markets (Beatty \& Ritter, 1986), and attract investors (Milgrom \& Roberts, 1986)". The boosted reputation firms receive from participating in CSR not only makes them 
more appealing to consumers, but to investors and suppliers as well. Furthering the point, Papoli (2015) states that the brand must be considered as a vector that allows CSR strategy to translate into competitive advantage; it assumes the role of "intersystemic connector" between the business system and the consumer system, because it allows the integration of CSR strategy (a firm's values and behavior) and the competitive strategy of the firm, unifying the cognitive and emotional associations that the brand arouses in consumers' minds. What this means is that firms are able to leverage their CSR strategies more with a valuable brand, meaning that brand and CSR play off of each other in more ways than one. This also means that CSR actions further a brand's reputation. McWilliams and Siegel (2011) fortify this concept when they state that: "a CSR strategy can be a valuable complement to a differentiation strategy, enhancing the value of the reputation and/or the brand of the firm". Tylenol was exemplified in the previous section as an early example of how CSR can lead to transparency, and in turn, trust from consumers. Another example of the impact of brand image is when Nike's was decimated in the 1990s after being revealed to be using "sweatshop" like working conditions and low wages in Asian countries to manufacture their products. The unethical behavior was not accepted by consumers, and the brand took a hit. Nike fixed the issues of the unethical labor conditions, and since 2005 has been reporting its commitments and factory audits (Nisen, 2013). The transparency and commitment to bettering working conditions allowed Nike to regain its reputation with consumers, and furthermore market share. The financial crisis of 2008-2009 in the United States and its impact of stakeholder trust will be reviewed in the final section.

\section{Employees}

Employees contribute to a company through their productivity. In order to be as productive (and in turn profitable) as possible, a company must attract and retain the best people possible. CSR has proved to be a factor that effects the recruitment, retention, and productivity 
of employees when CSR makes the company appear more favorable (Willard, 2002). Hiring and losing employees is very costly to a company, making employee retention a necessary activity. A study done in the UK by the Centre for Economics and Business Research (CEBR) and the UK's Federation of Small Business found that one-owner businesses with one employee incur an average cost of $\$ 56,777$ USD per worker and that businesses with between twenty and fourtynine employees incur an average cost of $\$ 40,165$ USD per worker. Because the hiring process is so costly, companies can use CSR to attract, retain, and boost employee performance. These points bring up the third research question of: Does CSR make firms more money via its employees?

In order to find the best employees, a firm must be able to attract the best employees. CSR can be used to attract talented employees. Nyborg and Brekke (2004) share that: "CSR is a labor market screening strategy that enables the firm to attract highly motivated and productive employees". The attraction of employees and the increased productivity of said employees could be rooted in a better cultural fit between the individual and the firm. Implementing CSR can save time in finding eligible candidates for vacant positons and be used as positive public relations with the potential applicant pool.

One way CSR can be used to lever productivity is through the promotion of it from managers. McWilliams and Siegel (2011) noted that: “managers' emphasis on CSR values was associated with followers' perceptions of visionary leadership, which positively influenced employees' extra effort, which in turn positively influenced firm performance" (Sully de Leque et al, 2008). Actions of managers influence one of a company's most valued assets which is culture. Culture starts from the top and can be demonstrated through CSR actions or commitments to CSR by managers. One of the most fundamental concepts of management is 
that leadership starts at the top, and good leadership increases followers' performance. CSR efforts can launch employee productivity and commitment through its culture, which was found by Ramus and Steger (2000) and also leads to employees whom "develop and implement creative ideas that positively affect the natural environment". A company with a unique way of embedding CSR practices into its employees' routines is the shoe manufacturer, Timberland. Each Timberland is given up to 40 hours per year of paid time to use for volunteer activities and service. In 2014, Timberland celebrated their one millionth service hour. McWilliams and Siegel (2011) noted other authors, Stuebs and Sun (2010: 265), as having found that: “[by] comparing America's Most Admired Companies to a matched sample of other firms, [results find] that 'reputation is associated with improved labor efficiency and labor productivity"'. CSR has been demonstrated as increasing productivity when it is exemplified by management. Another result of CSR involvement positively influencing employee performance is employee engagement and identification with the firm as summarize by Aguinas and Glavas (2012) as: "[t]he engagement and identification with the firm increases organizational citizenship behavior, retention, in-role performance, and commitment". Organizational citizenship behavior (OCB) is a term that can widely be defined as: "anything positive and constructive that employees do on their own terms benefiting the company" (Zhang, 2011). CSR can cause employees to feel more identified with their job and the firm, which increases organizational citizenship behavior. This means that more employees will strive to achieve what is beyond their job description, making the company more productive.

Additionally, an outcome of CSR actions in increased demographic diversity for firms. Johnson and Greening (1999) found that: "CSR initiatives have resulted in improved demographic diversity, especially regarding women and minorities". The workforce being more 
diverse is a growing trend. In 2010, the United States Department of Labor found that: "women are projected to account for 51 percent of the increase in total labor force growth between 2008 and 2018" and also that: "of employed women, 40.6 percent (the largest percentage) worked in management, professional, and related occupations". With more women continuing to enter the workforce, attraction and retention of women as employees is an increasing need. CSR initiatives can aid in the attraction, retention, and productivity of the changing demographics of the workforce.

CSR actions, when carried out by managers, contribute to more employee productivity through creativity and increased performance. CSR also acts as a way of attracting and retaining employees, which leads to less hiring costs of finding new employees when current employees stay longer and CSR actions act as a screening process and means of advertising for a firm. Initiatives by companies geared toward CSR also contribute to a huge asset to firms - their culture. By positively influencing the direction of a company's culture, a firm fosters more employee satisfaction and initiatives. With a growing trend of women and diversity in the workforce, CSR is also a way to attract those minority groups to a company.

\section{Finances}

It is difficult for a firm to spend money on something that will not result in a financial return. The same concept applies to CSR, unless a firm is acting in a completely altruistic manner. McWilliams and Siegel (2011) summarize this concept when they claim that managerial implications of corporate social responsibility are mostly focused on relationship between CSR and firm performance. The root of the firm's financial boost from CSR can stem from globalization advertising the good deeds to the world, enhanced brand image, or increased 
productivity in employees. The reasoning behind the implementation of CSR brings up a final research question: How does CSR improve a firm's financial performance?

The view of business by the world is not always the best, which can be accredited to numerous business scandals and the 2008-2009 financial crisis in the United States. When fraudulence happens, consumers trust in businesspeople wanes. Papoli (2015) summarizes this concept when he describes firms as being part of society, describing that the vision of the firm as a cell of a social system is not a new theme, but it certainly has been amplified by recent, notorious financial and social scandals that have made the world community more informed and aware of the diffuse presences of social irresponsible aspects of business. This means that firms are viewed as having a role to play in society. CSR being used by increasingly more firms may not be able to give the business world a better reputation, but it is being found to help individual firms have a better reputation. Lins, Servaes, and Tamayo (2016) found that: "[d]uring the 2008-2009 financial crisis, firms with high social capital, measured as corporate social responsibility (CSR) intensity, had stock returns that were four to seven percentage points higher than firms with low social capital. High-CSR firms also experienced higher profitability, growth, and sale per employee relative to low-CSR firms, and they raised more debt. This evidence suggests that the trust between the firm and both its stakeholders and investors, built through investments in social capital, pays off when the overall level of trust in corporations and markets suffers a negative shock". The data found enforces that firms who were using CSR gained more trust from consumers, stakeholders, and investors resulting in financial gains. This data can also reinforce the question on the relationship between CSR, trust, and branding. 
The impact of CEOs on a company is often measured and analyzed from a financial standpoint. As elaborated in the previous section, when CSR is carried out by managers, employee productivity increases. The financial gain from a CEO perspective was also noted by McWilliams and Siegel (2011) when they referenced Waldman, Siegel, and Javidan (2006) and Sully de Luque, Washburn, Waldman, and House (2008) and stated that: "CEOs who have such values were more effective leaders and that their firms, in turn, had superior financial performance". Affective leadership is often the core of a productive company. The evidence that CEOs can impact a firm's financial performance with the implementation of CSR adds to answering the final research question.

The enactment of CSR by firms has an effect on the company's brand image, which has implications that lead to financial gain. The effect on brand image stems from differentiation in the market. McWilliams and Siegel (2011) describe this process by sharing that: "a CSR strategy can be a valuable (in the RBT sense) complement to a differentiation strategy, enhancing the value of the reputation and/or the brand of the firm. The use of CSR creating a differentiation strategy can also enable a firm to charge a higher price for its goods or services because of the reputation behind them". As first noted by Forbrun and Shanley (1990) and then by McWilliams and Siegel (2011) point out that: "firms may make more profit through the use of CSR by gaining a better reputation with investors and reducing the cost of financial capital [and that] this could occur because by engaging in CSR the firm enhances its reputation among those providers of financial capital who are sensitive to the risks associated with a firm being perceived as "irresponsible" (e.g., the BP oil spill in the Gulf of Mexico and Union Carbide in Bhopal) as well as with investors who share an interest in a particular social practice (e.g., promoting diversity, community involvement, or the environment)". CSR can decrease the risk 
felt by investors and CSR can spark interest in investors who also have passions in similar areas of social action.

\section{Conclusion}

Through reviewing older articles, from the 2001-20012 time frame, and comparing the conclusions with newer articles from the 2015-2016 time frame, I was able to generate research questions and answer them. The results of the research question on globalization of: Will more firms participate in CSR as their audience grows? This question was meant to explore the effects of globalization and an increase in firms participating in CSR. The findings were that as the audience for CSR grew, more firms participated in CSR and the socially responsible actions were a result of a more open relationship between firms and society. Participation in CSR initiatives were also growing in number and in number of reportings. For the impact of CSR on a firm's brand, the following research question was generated: Can CSR be used to gain trust from consumers? Early examples of this were demonstrated by Tylenol in the 1980s and Nike in the 1990s. More recent findings were able to fortify the results on CSR building trust in consumers and the growth of consumers expecting firms to engage in CSR. For the effect on employees, it was found that the use of CSR by firms spurred better performance in employees as well as more commitment to the firm. CSR was also shown to be able to attract potential employees to a firm and act as a screening process for candidates. These findings were able to answer the third research question of: Can CSR cause a firm to make more money through its employees? The overarching theme behind these research questions relates to the impact of CSR in various areas of a firm and the impact on the firm's financial performance. The financial performance was the final research question of: How does CSR improve a firm's financial performance? 
Kron 16

\section{References}

Aguinis, H., \& Glavas, A. (2012). What We Know and Don't Know About Corporate Social Responsibility: A Review and Research Agenda. Journal of Management, 38(4), 933-968.

Auger, P., Devinney, T. M., Louviere, J. J., and Burke, P. F. (2008). Do Social Product Features have Value to Consumers?, International Journal of Research in Marketing, 25, 183-91. 
Carroll, A. B., \& Shabana, K. M. (2010). The business case for corporate social responsibility: A review of concepts, research and practice. International Journal of Management Reviews, 12, 85-105.

Clarkson, P., Overell, M., \& Chappele, L. (2011). Environmental reporting and itss relation to corporate environmental performance. Abacus, 47(1), 27-60.

Fisher, V.E. (2015). A Study of How CSR Rankings are Affected in a Globalized Economy. McNair Scholars Research Journal, 9(1), 62.

Fombrun, C., \& Shanley, M. 1990. What's in a name? Reputation building and corporate strategy. Academy of Management Journal, 33: 233-258.

Fry, L. W., Keim, G. D., \& Meiners, R. E. 1982. Corporate contributions: Altruistic or for-profit. Academy of Management Journal, 25: 94-106.

Greening, D. W., \& Gray, B. 1994. Testing a model of organizational response to social and political issues. Academy of Management Journal, 37: 467-498. Muller \& Kolk, 2010;

Hesse, J. (2014, October 30). The True Cost Of Hiring An Employee? Much More Than Their Salary. Retrieved from http://www.forbes.com/sites/jasonhesse/2014/10/30/here-is-the-true-cost-ofhiring-an-employee/\#b16a1813cffe

Hildebrand, D., Sen, S. and Bhattacharya, C.B. (2011). Corporate social responsibility: A corporate marketing perspective, European Journal of Marketing, Vol. 45 No. 9/10, pp. 1353-64. Peloza and Shang, 2011;

Johnson, R. A., \& Greening, D. W. 1999. The effects of corporate governance and institutional ownership types on corporate social performance. Academy of Management Journal, 42: 564-576.

Klein, B., \& Leffler, K. B. 1981. The role of market forces in assuring contractual performance. Journal of Political Economy, 89: 615-641.

Beatty, R., \& Ritter, J. 1986. Investment banking, reputation, and underpricing of initial public offerings. Journal of Financial Economics, 15: 213-232.

KPMG International Cooperative. (2015). International Survey of Corporate Responsibility, 30-36.

Lins, K.V., Servaes, H., \& Tamayo, A. (2016). Social Capital, Trust, and Firm Performance: The Value of Corporate Social Responsibility during the Financial Crisis. Journal of Finance, Fourthcoming, 1.

McWilliams, A \& Siegel, D. (2011). Creating and Capturing Value: Strategic Corporate Social Responsibility, Resource-Based Theory, and Sustainable Competitive Advantage. Journal of Management, 37(5), 1481-1493.

McWilliams, A., \& Siegel, D. 2001b. Profit-maximizing corporate social responsibility. Academy of Management Review, 26: 504-505.Willard 2002

Milgrom, P., \& Roberts, J. 1986. Advertising as a signal of product quality. Journal of Political Economy, 94: 796-82

Nisen, M. (2013, May 9). How Nike Solved Its Sweatshop Problem. Retrieved from http://www.businessinsider.com/how-nike-solved-its-sweatshop-problem-2013-5

Nyborg, K., \& Brekke, K. A. 2004. Moral hazard and moral motivation: Corporate social responsibility as labor market screening. Working paper no. 25/2004, University of Oslo Economics. Retrieved from http://ssrn.com/ abstract=645741.

Papoli, P. (2015). Reinforcing Intangible Assets through CSR in a Globalized World. Journal of Management Policies and Practices, 3(1), 23-30.

Ramus, C. A., \& Steger, U. 2000. The roles of supervisory support behaviors and environmental policy in employee "ecoinitiatives" at leading-edge European companies. Academy of Management Journal, 43: 605-626.

Rehak, J. (2002, March 23). Tylenol made a hero of Johnson \& Johnson: The recall that started them all. Retrieved from http://www.nytimes.com/2002/03/23/your-money/tylenol-made-a-hero-ofjohnson-johnson-the-recall-that-started.html?_r=0

Russell, Dale W. and Cristel Antonia Russell (2010). Here or there? Consumer reactions to corporate social responsibility initiatives: Egocentric tendencies and their moderators, Marketing Letters, $21,65-81$. 
Rupp, D. E. 2011. An employee-centered model of organizational justice and social responsibility. Organizational Psychology Review, 1: 72-94.

Rupp, D. E., Williams, C. A., \& Aguilera, R. V. 2010. Increasing corporate social responsibility through stakeholder value internalization (and the catalyzing effect of new governance): An application of organizational justice, self-determination, and social influence theories. In M. Schminke (Ed.), Managerial ethics: Managing the psychology of morality: 69-88. New York: Routledge.

SONY Corporation (2006). Corporate Social Responsibility Report 2006. Japan

Stuebs, M., \& Sun, L. 2010. Business reputation and labor efficiency, productivity and cost. Journal of Business Ethics, 96: 265-283.

Sully de Luque, M., Washburn, N. T., Waldman, D. A., \& House, R. J. 2008. Unrequited profit: How stakeholder and economic values relate to subordinates' perceptions of leadership and firm performance. Administrative Science Quarterly, 53: 626-654

van Gelder S. (2002). General Strategies for Global Brands, Brand Meta - Global Brand Strategy, 1-10.

Waldman, D. A., Siegel, D., \& Javidan, M. 2006. Components of CEO transformational leadership and corporate social responsibility. Journal of Management Studies, 43: 1703-1725

Weaver, G. R., Treviño, L. K., \& Cochran, P. L. 1999a. Corporate ethics programs as control systems: Influences of executive commitment and environmental factors. Academy of Management Journal, 42: 41-57.

Weaver, G. R., Treviño, L. K., \& Cochran, P. L. 1999b. Integrated and decoupled corporate social performance: Management commitments, external pressures, and corporate ethics practices. Academy of Management Journal, 42: 539-552.

Willard, B. 2002. The sustainability advantage: Seven business case benefits of a triple bottom line. Gabriola Island, BC, Canada: New Society Publishers.

Zhang, D. 2011. Organisational citizenship behavior. Retrieved from https://cdn.auckland.ac.nz/assets/psych/about/our-people/documents/Deww\%20Zhang\%20\%20Organisational\%20Citizenship\%20Behaviour\%20-\%20White\%20Paper.pdf

Zyglidopoulos, Z. C., Georgiadis, A. P., Carroll, C., \& Siegel, D. S. 2009. The evolution of corporate social performance and the role of media visibility. Retrieved from http://papers.ssrn.com/sol3/papers.cfm?abstract_id=1514385 